JIIA, VOLUME 6 No. 3, AGUSTUS 2018

\title{
PENDAPATAN USAHATANI POLIKULTUR UDANG WINDU-IKAN BANDENG DAN EFISIENSI PEMASARAN IKAN BANDENG DI KECAMATAN PASIR SAKTI KABUPATEN LAMPUNG TIMUR
}

\author{
(Income Tiger Shrimp-Milkfish and Marketing Efficiency Analysis of Milkfish in Pasir Sakti Subdistrict of \\ East Lampung Regency)
}

Aldila Putri, Sudarma Widjaya, Eka Kasymir

\begin{abstract}
This study aimed to analyze income of tiger shrimp-milkfish and marketing efficiency of milkfish in Pasir Sakti subdistrict of east Lampung Regency. The research location was choosen purposely in Pasir Sakti Subdistrict Lampung Regency. Data of this research was collected during November-January 2016. Respondents of this research were 64 cultivators and 40 traders. This research used survey method, in which samples were chosen by simple random sampling and snowball sampling. The collected data, included primary and secondary data, was analyzed by descriptive qualitative analysis, income analysis, and marketing margins. The results showed that tiger shrimp and milkfish aquaqulture were profitable. There were 2 channels of marketing of milkfish but both of them were inefficient. Marketing margin and profit margin ratio on marketing of milkfish were not prevalent.
\end{abstract}

Key words: Income, marketing efficiency, milkfish

\section{PENDAHULUAN}

Produksi udang windu di Indonesia mengalami penurunan ditahun 2014. Hal ini disebabkan beberapa faktor seperti penyakit dan menurunnya daya dukung lingkungan (Direktorat Jenderal Perikanan Budidaya 2016). Kabupaten Lampung Timur merupakan kabupaten yang memproduksi ikan bandeng tertinggi sedangkan produksi udang windu terendah di Provinsi Lampung. Oleh karena itu perlu dilakukan penelitian tentang usahatani pada kedua komoditas tersebut.

Provinsi Lampung menepati urutan ke empat belas sebagai sentra produksi ikan bandeng di Indonesia (Direktorat Jenderal Perikanan Budidaya 2016). Rata-rata produktivitas ikan bandeng di Kabupaten Lampung Timur adalah $750 \mathrm{~kg} / \mathrm{ha}$. Produktivitas dapat ditingkatkan melalui penggunaan jumlah faktor produksi dan dapat berpengaruh terhadap pendapatan petani (Mubyarto 1989). Budidaya ikan bandeng dan udang windu di Kecamatan Pasir Sakti Kabupaten Lampung Timur saat ini masih menggunakan pola polikultur.

Sistem pemasaran yang terjadi di Kecamatan Pasir Sakti pada komoditas ikan bandeng dan udang windu berbeda, yaitu pada pola pemasaran udang windu telah berjalan baik, karena udang windu bisa langsung dijual ke pabrik, sedangkan sistem pemasaran ikan bandeng, harga yang diterima pembudidaya berfluktuasi.

Kecamatan Pasir Sakti memiliki enam desa yang penduduknya melakukan budidaya tambak. Desa Mulyosari dan Desa Pasir Sakti merupakan desa yang memiliki pembudidaya ikan bandeng dan udang windu tertinggi di Kecamatan Pasir Sakti Kabupaten Lampung Timur. Berdasarkan uraianuraian diatas, maka dilakukan penelitian tentang pendapatan usahatani ikan bandeng dan udang windu serta efisiensi pemasaran ikan bandeng di Kecamatan Pasir Sakti Kabupaten Lampung Timur.

\section{METODE PENELITIAN}

Penelitian ini dilaksanakan di Kecamatan Pasir Sakti Kabupaten Lampung Timur. Lokasi penelitian dipilih secara sengaja (purposive). Pemilihan Kabupaten Lampung Timur menjadi daerah penelitian atas dasar pertimbangan bahwa Kabupaten Lampung Timur merupakan sentra dan produksi tertinggi ikan Bandeng di Provinsi Lampung.

Pengambilan data dilaksanakan pada bulan November 2016 sampai dengan bulan Januari 2017. Sampel penelitian ini adalah petani pola polikultur tradisional ikan bandeng dan udang windu serta lembaga pemasaran yang ikut terlibat dalam kegiatan pemasaran di lokasi penelitian. Jumlah populasi petani ikan bandeng di Desa 
Mulyosari 239 orang dan Desa Pasir Sakti 168 orang, sehingga jumlah populasi di kedua desa tersebut adalah 407, dan ditentukan jumlah sampel dengan menggunakan rumus yang merujuk pada teori Sugiarto 2003 dalam Handayani 2011 :

$\mathrm{n}=\frac{\mathrm{NZ}^{2} \mathrm{~S}^{2}}{\mathrm{Nd}^{2}+\mathrm{Z}^{2} \mathrm{~S}^{2}}$

Keterangan:

$\mathrm{n}=$ Jumlah sampel

$\mathrm{N}=$ Jumlah populasi

$\mathrm{S}^{2}=$ Variasi sampel $(5 \%=0,05)$

$\mathrm{Z}=$ Tingkat kepercayaan $(95 \%=1,96)$

$\mathrm{d}=$ Derajat penyimpangan $(5 \%=0,05)$

Berdasarkan perhitungan dengan menggunakan rumus di atas diperoleh jumlah sampel sebanyak 64 orang ikan bandeng. Alokasi sampel kedua desa ditentukan secara proposional, kemudian diperoleh jumlah sampel Desa Mulyosari sebanyak 37 orang dan Desa Pasir Sakti sebanyak 27 orang. Pengambilan sampel petani menggunakansimple random sampling. Pengambilan sampel pada lembaga pemasaran menggunakan metode snowball sampling, dengan jumlah sampel pemasaran sebanyak 3 pedagang pengumpul, 8 pedagang besar, dan 18 pedagang pengecer dan 11 pedagang pengecer lokal.

Metode analisis data yang digunakan adalah metode analisis deskriptif kualitatif dan kuantitatif. Data yang digunakan dalam penelitian ini terdiri dari data primer dan data sekunder.

\section{Analisis Pendapatan Usahatani Polikultur Ikan Bandeng dan Udang Windu}

Pendapatan dari suatu model usahatani ikan bandeng dapat dihitung menggunakan rumus sebagai berikut (Soekartawi 1995):

$\pi=\mathrm{TR}-\mathrm{TC}$

Keterangan :

$\pi=$ Keuntungan/pendapatan $(\mathrm{Rp})$

$\mathrm{TR}=$ Total Revenue (total penerimaan) $(\mathrm{Rp})$

$\mathrm{TC}=$ Total Cost (total biaya) (Rp)

Menguntungkan atau tidak usahatani dapat dianalisis dengan menggunakan revenue cost ratio $(R / C)$. Nilai $\mathrm{R} / \mathrm{C}$ rasio diperoleh dengan menggunakan :

$\mathrm{R} / \mathrm{C}=\mathrm{NPT} / \mathrm{BT}$
Keterangan:

$\mathrm{R} / \mathrm{C}=$ Nisbah antara penerimaan dan biaya

NPT $=$ Nilai produk total

$\mathrm{BT}=$ Biaya total

a. Jika $\mathrm{R} / \mathrm{C}=1$, makausahatani berada dalam titik impas.

b. Jika $\mathrm{R} / \mathrm{C}<1$, makausahatani tidak menguntungkan.

c. Jika R/C $>1$, makausahatanimenguntungkan.

Analisis yang digunakan untuk menganalisis organisasi suatu pasar adalah analisis dengan model S-C-P. Analisis pangsa produsen digunakan untuk mengetahui bagian harga yang diterima produsen. Semakin tinggi pangsa produsen maka kinerja pasar semakin baik dari sisi produsen, diukur dengan rumus (Hasyim 2012) :

$\mathrm{PS}=\frac{\mathrm{Pf}}{\mathrm{Pr}} \times 100 \%$

Keterangan :

$\mathrm{PS}=$ Harga ikan bandeng yang diterima petani

$\mathrm{Pf}=$ Harga ikan bandeng di tingkat produsen

$\operatorname{Pr}=$ Harga ikan bandeng di tingkat konsumen

Marjin pemasaran adalah perbedaan harga pada tingkat produsendengan harga di tingkat eceran atau konsumen (Hasyim, 2012). Secara matematis, marjin pemasaran dirumuskan sebagai:

Mji=Psi-Pb
Mji=bti $+\pi \mathrm{i}$
$\pi \mathrm{i}=$ Mji-bti

Penyebaran marjin pemasaran dapat dilihat berdasarkan persentase keuntungan terhadap biaya pemasaran pada masing-masinglembaga pemasaran (Hasyim 2012):

$\mathrm{RPM}=\frac{\pi \mathrm{i}}{\mathrm{bti}}$

Keterangan :

$\mathrm{Mji}=$ Marjin pada lembaga tata niaga ke- $\mathrm{i}$

Psi = Harga penjualan lembaga tata niaga ke- $\mathrm{i}$

Pbi = Harga pembelian lembaga tata niaga ke-i

$\mathrm{Bi}$ = Biaya tataniaga pada lembaga tata niaga ke-i

$\pi \mathrm{i}=$ Keuntungan yang diperoleh lembaga tataniaga ke-i

\section{HASIL DAN PEMBAHASAN}

Responden petani polikultur ikan bandeng dan udang windu di Kecamatan Pasir Sakti berjenis kelamin laki-laki dengan sebaran umur responden 
yaitu berkisar $30-63$ tahun. Hal ini menunjukkan bahwa umur pembudidaya polikultur di lokasi penelitian ini berada pada kelompok umur produktif.

Petani ikan bandeng dan udang windu di lokasi penelitian sebagian besar merupakan lulusan SD dengan jumlah yaitu sebanyak 28 orang $(43,75 \%)$, sehingga pembudidaya diasumsikan tidak mengutamakan pendidikan. Pekerjaan utama responden petani merupakan petani tambak, sedangkan petani yang memiliki pekerjaan sampingan yaitu penjual nener, buruh, dan ojek ikan sebanyak 8 orang $(12,50 \%)$.

Luas lahan yang dimiliki responden sebagian besar 0 - 2 ha $(43,75 \%)$ sebanyak 28 orang dengan pengalaman usahatani yang cukup lama sekitar 6 33 tahun. Status kepemilikan lahan responden seluruhnya adalah milik sendiri. Pajak yang harus dibayarkan yaitu sebesar Rp35.000,00/Ha/Th.

Budidaya polikultur ikan bandeng dan udang windu terdiri dari persiapan tambak, pemupukan dasar tambak, pemeliharaan tambak, dan pemanenan. Tenaga kerja yang digunakan dalam berusahatani polikultur seluruhnya berjenis kelamin laki-laki dengan upah tenaga kerja sebesar Rp70.000,00/hari.

\section{Budidaya Polikultur Ikan Bandeng dan Udang Windu}

Ikan bandeng dan udang windu merupakan komoditas perikanan yang banyak dibudidayakan di Kecamatan Pasir Sakti Kabupaten Lampung Timur. Persiapan tambak merupakan langkah awal dalam proses pembesaran ikan bandeng dan udang windu, terdiri dari pengeringan dasar tambak, pembersihan lumpur, pemberantasan hama dan pemupukan dasar tambak.

Persiapan tambak membutuhkan waktu sekitar sebulan. Pemberantasan hama meng-gunakan saponin dengan dosis $20-25 \mathrm{Kg} / \mathrm{ha}$. Pemupukan dasar tambak berguna untuk menumbuhkan pakan alami dan pemasok unsur hara yang dibutuhkan oleh ikan bandeng dan udang windu. Jenis pupuk yang digunakan yaitu pupuk organik dan pupuk anorganik (Urea dan SP36) sebanyak 50 - 100 $\mathrm{Kg} / \mathrm{ha}$.

Penebaran nener dan benur dilakukan setelah persiapan tambak selesai.Proses penebaran nener dan benur tidak dilakukan bersamaan, melainkan penebaran nener terlebih dahulu, setelah 20 - 30 hari dilakukan penebaran benur. Hal ini bertujuan agar mencapai ukuran konsumsi dalam waktu yang bersamaan.

Pemeliharaan tambak pada kegiatan budidaya polikultur ikan bandeng dan udang windu terdiri dari pemupukan susulan, pemberian pakan, vitamin, serta memonitoring pertumbuhan ikan bandeng dan udang windu. Pemupukan susulan diberikan saat pakan alami hampir habis atau sekitar 2 minggu sekali dengan dosis $5-15 \mathrm{Kg} / \mathrm{ha}$.

Vitamin diberikan seminggu sekali dicampurkan pada saat pemberian pakan. Pemberian pakan ditujukan untuk udang windu. Pemeliharaan tambak membutuhkan waktu sekitar 150 - 180 hari hingga panen. Pemanenan dilakukan saat ikan bandeng dan udang windu telah mencapai ukuran konsumsi dengan cara dipanen total.

\section{Analisis Pendapatan Usahatani Ikan Bandeng dan Udang Windu}

Analisis usahatani dilakukan untuk mengetahui apakah suatu usahatani menguntungkan atau tidak, layak atau tidak suatu usahatani dan untuk melihat cara penggunaan input produksi, tenaga kerja, penyusutan peralatan, produksi yang dihasilkan, dan pendapatan. Biaya dalam usahatani ini meliputi biaya tunai yang terdiri dari biaya input produksi, biaya tenaga kerja (biaya TKLK), biaya pajak dan biaya sewa lahan. Biaya diperhitungkan meliputi biaya tenaga kerja (TKDK), biaya lahan sendiri, dan biaya penyusutan alat.

Rasio antara penerimaan dan total biaya (R/C) atas biaya tunai ikan bandeng dan udang windu adalah sebesar 3,90 dan rasio antara penerimaan dan total biaya $(\mathrm{R} / \mathrm{C})$ atas biaya tunai adalah sebesar 2,50, Rasio tersebut memiliki nilai lebih besar dari satu $(\mathrm{R} / \mathrm{C}>1)$ yang berarti usahatani sistem polikultur udang windu dan ikan bandeng di Kecamatan Pasir Sakti layak dan menguntungkan.

Hal ini sejalan dengan penelitian Susanti et al. (2016) yang menghasilkan nilai $\mathrm{R} / \mathrm{C}$ rasio atas biaya total sebesar 2,87 pada usahatani ikan patin di Kabupaten Lampung Tengah dan sejalan juga dengan penelitian Annisa et al. (2014) usaha tambak bandeng di Desa Dolago layak untuk diusahakan dengan $\mathrm{R} / \mathrm{C}$ rasio 2,70 . Perhitungan pendapatan usahatani disajikan pada Tabel 1 . 
Tabel 1. Rata-rata pendapatan usahatani ikan bandeng dan udang windu di Kecamatan Pasir Sakti Kabupaten Lampung Timur, 2016

\begin{tabular}{|c|c|c|c|c|c|}
\hline Uraian & Satuan & Jumlah & Harga (Rp) & Nilai (Rp/3,27 ha) & Nilai (Rp/ha) \\
\hline \multicolumn{6}{|l|}{ Penerimaan } \\
\hline Produksi Ikan Bandeng & $\mathrm{Kg}$ & $3.650,06$ & $12.750,00$ & $46.538 .296,88$ & $14.231 .895,07$ \\
\hline Produksi Udang Windu & $\mathrm{Kg}$ & 880,78 & $88.484,38$ & $77.935 .378,42$ & $23.833 .449,06$ \\
\hline Total Penerimaan & & & & $124.473 .675,29$ & $38.065 .344,13$ \\
\hline $\begin{array}{l}\text { Biaya Produksi } \\
\text { 1. Biaya Tunai } \\
\text { Benih }\end{array}$ & & & & & \\
\hline Nener & Ekor & $13.325,00$ & 94,27 & $1.256 .089,45$ & $384.125,22$ \\
\hline Benur & Ekor & $29.453,00$ & 41,95 & $1.235 .645,39$ & $377.873,21$ \\
\hline \multicolumn{6}{|l|}{ Pupuk } \\
\hline SP36 & $\mathrm{Kg}$ & 613,43 & $2.320,59$ & $1.423 .521,63$ & $435.327,71$ \\
\hline Urea & $\mathrm{Kg}$ & 765,70 & $2.097,40$ & $1.605 .979,18$ & $491.125,13$ \\
\hline Organik & $\mathrm{Kg}$ & $1.001,85$ & $1.086,67$ & $1.088 .679,01$ & $332.929,36$ \\
\hline \multicolumn{6}{|l|}{ Vitamin } \\
\hline Raja Bandeng & $\mathrm{Kg}$ & 81,19 & $12.043,75$ & $977.801,95$ & $299.022,00$ \\
\hline Probiotik & Liter & 32,81 & $60.000,00$ & $1.968 .750,00$ & $602.064,22$ \\
\hline Linex Super & $\mathrm{Kg}$ & 16,38 & $42.062,50$ & $688.773,44$ & $210.634,08$ \\
\hline \multicolumn{6}{|l|}{ Obat } \\
\hline Dolomit & $\mathrm{Kg}$ & 705,00 & 896,88 & $632.296,88$ & $193.362,96$ \\
\hline Saponin & $\mathrm{Kg}$ & 73,39 & $6.000,00$ & $440.343,75$ & $134.661,70$ \\
\hline \multicolumn{6}{|l|}{ Pakan } \\
\hline Haima & $\mathrm{Kg}$ & 943,37 & $5.243,02$ & $4.946 .121,82$ & $1.512 .575,48$ \\
\hline Sumber Sari Laut & $\mathrm{Kg}$ & 897,36 & $3.102,27$ & $2.783 .866,74$ & $851.335,39$ \\
\hline Siput & $\mathrm{Kg}$ & 80,20 & $3.500,00$ & $280.710,94$ & $85.844,32$ \\
\hline Biaya TKLK & $\mathrm{HOK}$ & 178,95 & $70.000,00$ & $12.526 .171,88$ & $3.830 .633,60$ \\
\hline Pajak & $\mathrm{Rp}$ & & & $57.148,44$ & $17.476,59$ \\
\hline Sewa & $\mathrm{Rp}$ & & & 0,00 & 0,00 \\
\hline Total Biaya Tunai & & & & $31.911 .900,49$ & $9.758 .990,97$ \\
\hline \multicolumn{6}{|l|}{ II. Biaya Diperhitungkan } \\
\hline Biaya TKDK & HOK & 10,63 & $70.000,00$ & $743.750,00$ & $227.446,48$ \\
\hline Sewa Lahan Sendiri & $\mathrm{Rp}$ & & & $16.328 .125,00$ & 4.993.310,40 \\
\hline Penyusutan Alat & $\mathrm{Rp}$ & & & $901.558,22$ & $275.705,88$ \\
\hline Total Biaya Diperhitungkan & & & & $17.973 .433,22$ & $5.496 .462,76$ \\
\hline Total Biaya & & & & $49.885 .333,71$ & $15.255 .453,73$ \\
\hline \multicolumn{6}{|l|}{ Pendapatan } \\
\hline I. Pendapatan atas biaya tunai & & & & $92.561 .774,81$ & 28.306.353,15 \\
\hline II. Pendapatan atas biaya total & & & & $74.588 .341,59$ & $22.809 .890,39$ \\
\hline \multicolumn{6}{|l|}{$\mathrm{R} / \mathrm{C}$} \\
\hline I. $\mathrm{R} / \mathrm{C}$ atas biaya tunai & & & & 3,90 & 3,90 \\
\hline II. $\mathrm{R} / \mathrm{C}$ atas biaya total & & & & 2,50 & 2,50 \\
\hline
\end{tabular}

\section{Analisis Efisiensi Pemasaran Ikan Bandeng}

Efisiensi pemasaran ikan bandeng dapat dianalisis melalui model SCP (Structure, Conduct, and Performance). Pemasaran udang windu prosesnya berbeda dengan pemasaran ikan bandeng. Pada pemasaran udang windu bisa langsung dijual ke pabrik, melalui proses penyortiran seperti pemilihan udang yang segar, tidak ada kecacatan, dan bobot udang atau ukuran udang sesuai standar yang ditetapkan pabrik. Pada penelitian ini, pemasaran yang akan dibahas adalah pemasaran ikan bandeng, yaitu sebagai berikut.

Pedagang pengumpul membeli ikan bandeng langsung dari pembudidaya dan umumnya melakukan pembelian ditingkat desa maupun antar desa. Pedagang pengumpul menjual ikan bandeng ke pedagang besar dan ke pedagang pengecer lokal. Kegiatan pembelian dilakukan dengan cara pembudidaya menghubungi pedagang pengumpul. Hal ini karena pembudidaya dan pedagang pengumpul saling mengenal, kerabat, atau saling bekerjasama. Hasil pembelian pedagang pengumpul mengangkut ikan ke tempatnya, untuk dilakukan pencucian, dan penimbangan. Selanjutnya ikan bandeng akan dijual kembali ke pedagang besar dan pedagang pengecer lokal. Harga ditentukan dari proses tawar menawar, pembudidaya memiliki posisi tawar yang lemah.

Pedagang besar yang membeli ikan bandeng di Kecamatan Pasir Sakti berasal dari Provinsi Banten 
dan Jakarta. Kegiatan pembelian pedagang besar dengan cara menghubungi pedagang pengumpul untuk mengirimkan ikan bandeng. Pengiriman dilakukan setiap hari. Biaya yang dikeluarkan oleh pedagang besar antara lain biaya transportasi, biaya tenaga kerja, dan biaya pengemasan. Harga yang terjadi melalui proses tawar menawar.

Pedagang pengecer dalam penelitian ini adalah pedagang yang menjual ikan bandeng dari pedagang besar. Transaksi yang dilakukan adalah ikan bandeng di ambil dari pedagang besar. Pedagang pengecer juga dapat memesan kembali kepada besar apabila persediaan ikan bandeng yang dimiliki telah habis. Jika ikan tidak habis dijual maka pedagang pengecer melakukan penyimpanan.

Pedagang pengecer lokal merupakan pedagang pengecer yang berada di Kecamatan Pasir sakti. Pembelian ikan bandeng langsung ke pedagang pengumpul ikan bandeng di Kecamatan Pasir Sakti. Kegiatan pemasarannya, yaitu pedagang pengecer lokal langsung mendatangi pedagang pengumpul. Harga yang terjadi melalui proses tawar menawar.

\section{Struktur Pasar( Market Structure)}

Struktur pasar ikan bandeng di daerah penelitian dapat diidentifikasi dengan melihat jumlah lembaga pemasaran yang terlibat, sifat produk, sumber informasi dan hambatan keluar masuk pasar. Terdapat lima lembaga pemasaran dalam saluran pemasaran ikan bandeng di Kecamatan Pasir Sakti yaitu pembudidaya ikan bandeng, pedagang pengumpul, pedagang besar, pedagang pengecer, dan pedagang pengecer lokal.

Lembaga pemasaran yang menjadi responden dan terlibat dalam sistem pemasaran ikan bandeng di Kabupaten Lampung Timur terdiri dari 64 orang petani produsen, 3 pedagang pengumpul, 8 pedagang besar, dan 18 pedagangpengecer, serta 11 pedagang pengecer lokal. Ikan bandeng yang dijual oleh petani responden dan pedagang pengumpul mempunyai karakteristik sama.

Struktur pasar pada pembudidaya mengarah pada oligopsoni, sedangkan pada pedagang pengumpul, pedagang besar, dan pedagang pengecer mengarah pada oligopoli.Hasilpenelitianinipernah dilakukan pada penelitian Ali et al. (2017) dengan komoditas kubis yang menunjukkan bahwa struktur pasar kubis yaitu oligopsoni.

\section{Perilaku Pasar (Market Conduct)}

Proses pembentukan harga antara pembudidaya ikan bandeng dengan lembaga perantara adalah melalui proses tawar menawar. Pembudidaya ikan bandeng di lokasi penelitian sebagian besar menjadi penerima harga yang telah ditentukan oleh pedagang perantara yang dipilih.

Pembentukan harga di antara lembaga pemasaran yaitu dengan membentuk kesepakatan harga berdasarkan penawaran dan permintaan. Penjual dan pembeli melakukan proses tawar menawar sampai kedua belah pihak menyepakati harga.

Terdapat dua sistem pembayaran yang dilakukan oleh lembaga pemasaran ikan bandeng di Kecamatan Pasir Sakti, yaitu sistem bayar kemudian (bayar tunda) dan sistem pembayaran tunai.

\section{Keragaan Pasar (Market Performance)}

Dalam penelitian ini, keragaan pasar dapat dilihat dalam beberapa indikator, yaitu saluran pemasaran, pangsa produsen, marjin, dan rasio profit marjin.

\section{a. Saluran Pemasaran}

Saluran pemasaran yang terbentuk di Kecamatan Pasir Sakti Lampung Timur terdiri dari 2 saluran.

1. Saluran pemasaran 1: Pembudiaya - pedagang pengumpul - pedagang besar - pedagang pengecer - konsumen.

2. Saluran pemasaran 2 : pembudidaya pedagang pengumpul - pedagang pengecer lokal - konsumen.

Saluran pemasaran pertama, pembudidaya ikan bandeng menjual ikan ke pedagang pengumpul, ikan dijual ke pedagang besar, kemudian ikan dijual kembali ke pedagang pengecer. Pedagang pengumpul mengantarkan ikan bandeng ke pedagang besar biasanya pada sore hari dengan volume $300-400 \mathrm{Kg} / \mathrm{hari}$ sesuai permintaan pedagang besar.

Biaya pemasaran ditanggung oleh pedagang pengumpul. Pedagang besar melakukan penjualan kembali ke pedagang pengecer. Pedagang pengecer biasanya mengambil ikan pada waktu pagi hari dengan volume $20-130 \mathrm{Kg} / \mathrm{hari}$. Kemudian dari pedagang pengecer ikan langsung dijual kepada konsumen akhir. 
Saluran pemasaran kedua, dari pedagang pengumpul ikan bandeng kemudian di jual kepada pedagang pengecer lokal di Kecamatan Pasir Sakti. Pedagang pengumpul biasanya menjual ikan bandeng ke pedagang pengecer lokal dengan volume sekitar $10-30 \mathrm{Kg} /$ hari. Hal ini tergantung permintaan dari pedagang pengecer lokal tersebut. Pedagang pengecer lokal langsung menjual ikan bandeng kepada konsumen akhir.

\section{b. Pangsa Produsen (Producer Share)}

Harga yang diterima pembudidaya ikan bandeng relatif rendah, meskipun telah ditentukan oleh kesepakatan melalui sistem tawar-menawar, karena posisi tawar pembudidaya yang rendah. Pangsa produsen (producer's share) terkecil yang diterima pembudidaya adalah sebesar 51,46\% yang terdapat pada saluran pemasaran pertama, kecilnya Pangsa produsen pada saluran pertama diakibatkan oleh selisih harga yang diterima pembudidaya dengan konsumen akhir relatif lebih tinggi dibandingkan saluran lainnya.

\section{c. Margin Pemasaran}

Indikator yang digunakan untuk menentukan efisiensi suatu sistem pemasaran adalah menggunakan margin pemasaran. Margin pemasaran atau margin tataniaga adalah perbedaan harga di antara tingkat lembaga dalam sistem tataniaga atau perbedaan antara jumlah yang harus dibayar konsumen dan jumlah yang diterima produsen atas produk agribisnis yang diperjual belikan (Hasyim 2012).

Saluran pemasaran pertama menunjukkan bahwa marjin keuntungan terbesar yaitu Rp3.711,50/Kg diperoleh oleh pedagang pengecer. Selisih harga yang diterima oleh produsen dan yang diterima oleh konsumen cukup besar. Nilai pangsa yang diterima oleh produsen sebesar $53,13 \%$ dari harga yang diterima oleh konsumen. Marjin pemasaran ikan bandeng di Kecamatan Pasir Sakti pada saluran pertama, dapat dilihat pada Tabel 2 .
Tabel 2. Margin tataniaga ikan bandeng di Kecamatan Pasir Sakti saluran pemasaran I, 2016

\begin{tabular}{|c|c|c|c|}
\hline No & Uraian & $\begin{array}{c}\text { Margin } \\
(\mathrm{Rp} / \mathrm{Kg})\end{array}$ & $\begin{array}{c}\text { Pangsa } \\
\text { Produse } \\
\mathrm{n}(\%)\end{array}$ \\
\hline 1 & Harga jual petani & $12.750,00$ & 53,13 \\
\hline \multirow[t]{10}{*}{2} & Pedagang Pengumpul & & \\
\hline & a. Harga beli & $12.750,00$ & 53,13 \\
\hline & b. Biaya total & $2.867,84$ & 11,95 \\
\hline & - Biaya transportasi & $1.925,64$ & \\
\hline & - Biaya Tk & 627,23 & \\
\hline & - Biaya Pengemasan & 314,97 & \\
\hline & c. Margin Pemasaran & $3.750,00$ & 15,63 \\
\hline & d. Marjin Keuntungan & 882,16 & 3,68 \\
\hline & e. Harga jual & $16.500,00$ & 68,75 \\
\hline & f. Rasio Profit Margin & 0,31 & \\
\hline \multirow[t]{11}{*}{3} & Pedagang Besar & & \\
\hline & a. Harga beli & $16.500,00$ & 68,75 \\
\hline & b. Biaya total & 984,49 & 4,10 \\
\hline & - Biaya transportasi & 131,54 & \\
\hline & - Biaya Tk & 607,47 & \\
\hline & - Biaya & 245,49 & \\
\hline & Pengemasan & & \\
\hline & c. Margin Pemasaran & $3.500,00$ & 14,58 \\
\hline & d. Marjin Keuntungan & $2.515,51$ & 10,48 \\
\hline & e. Harga jual & $20.000,00$ & 83,33 \\
\hline & f. Rasio Profit Margin & 2,56 & \\
\hline \multirow[t]{11}{*}{4} & Pedagang Pengecer & & \\
\hline & a. Harga beli & $20.000,00$ & 83,33 \\
\hline & b. Biaya Total & 288,50 & 1,20 \\
\hline & - Biaya transportasi & 136,51 & \\
\hline & - Biaya Tk & 0,00 & \\
\hline & - Biaya & 151.99 & \\
\hline & Pengemasan & & \\
\hline & c. Margin Pemasaran & $4.000,00$ & 16,67 \\
\hline & d. Marjin Keuntungan & $3.711,50$ & 15,46 \\
\hline & e. Harga jual & $24.000,00$ & 100,00 \\
\hline & f. Rasio Profit Margin & 12,86 & \\
\hline 5 & Konsumen & $24.000,00$ & 100,00 \\
\hline
\end{tabular}

Saluran pemasaran kedua menunjukkan bahwa margin keuntungan terbesar diperoleh oleh pedagang pengumpul dan pangsa pasar serta nilai RPM masing-masing lembaga pemasaran memiliki kesenjangan yang relatif tinggi sehingga saluran pemasaran pertama dan kedua belum efisien. Penelitian ini pernah dilakukan pada penelitian Kesuma et al. (2016) dengan komoditas bawang merah yang menunjukkan bahwa sistem pemasaran bawang merah di Kabupaten Tanggamus belum efisien dan margin disetiap lembaga pemasaran masih terlalu besar. Saluran pemasaran ke dua dapat dilihat pada Tabel 3. 
Tabel 3. Margin tataniaga ikan bandeng di Kecamatan Pasir Sakti saluran pemasaran II, 2016

\begin{tabular}{|c|c|c|c|}
\hline No & Uraian & $\begin{array}{c}\text { Margin } \\
(\mathrm{Rp} / \mathrm{Kg})\end{array}$ & $\begin{array}{l}\text { Pangsa } \\
\text { Produsen } \\
(\%)\end{array}$ \\
\hline 1 & Harga jual petani & $12.750,00$ & 55,43 \\
\hline \multirow[t]{9}{*}{2} & $\begin{array}{l}\text { Pedagang } \\
\text { Pengumpul }\end{array}$ & & \\
\hline & a. Harga beli & $12.750,00$ & 55,43 \\
\hline & b. Biaya total & 63,07 & 0,27 \\
\hline & $\begin{array}{c}\text { - Biaya } \\
\text { transportasi }\end{array}$ & 0,00 & \\
\hline & - Biaya Tk & 0,00 & \\
\hline & $\begin{array}{c}\text { - Biaya } \\
\text { Pengemasan }\end{array}$ & 63,07 & \\
\hline & $\begin{array}{l}\text { c. Margin } \\
\text { Pemasaran }\end{array}$ & $4.550,00$ & 19,78 \\
\hline & $\begin{array}{l}\text { d. Marjin } \\
\text { Keuntungan }\end{array}$ & $4.486,93$ & 19,51 \\
\hline & $\begin{array}{l}\text { e. Harga jual } \\
\text { f. RPM }\end{array}$ & $\begin{array}{r}17.300,00 \\
71,13\end{array}$ & 75,22 \\
\hline \multirow[t]{10}{*}{3} & Pedagang Pengecer & & \\
\hline & a. Harga beli & $17.300,00$ & 75,22 \\
\hline & b. Biaya total & 754,52 & 3,28 \\
\hline & $\begin{array}{c}\text { - Biaya } \\
\text { transportasi }\end{array}$ & 679,61 & \\
\hline & - Biaya Tk & 0,00 & \\
\hline & $\begin{array}{c}\text { - Biaya } \\
\text { Pengemasan }\end{array}$ & 74,91 & \\
\hline & $\begin{array}{l}\text { c. Margin } \\
\text { Pemasaran }\end{array}$ & $5.700,00$ & 24,78 \\
\hline & $\begin{array}{l}\text { d. Marjin } \\
\text { Keuntungan }\end{array}$ & $4.945,48$ & 21,50 \\
\hline & e. Harga jual & $23.000,00$ & 100,00 \\
\hline & $\begin{array}{l}\text { f. Rasio Profit } \\
\text { Margin }\end{array}$ & 6,55 & \\
\hline 4 & Konsumen & $23.000,00$ & 100,00 \\
\hline
\end{tabular}

Tabel 3 menunjukkan bahwa Margin keuntungan terbesar yaitu $\mathrm{Rp} 4.945,48 / \mathrm{Kg}$ diperoleh oleh pedagang pengumpul. Selisih harga yang diterima produsen dan yang diterima oleh konsumen cukup besar. Nilai pangsa yang diterima oleh produsen yaitu sebesar 55,43\% dari harga yang diterima oleh konsumen.

\section{KESIMPULAN}

Pendapatan usahatani polikultur tradisional ikan bandeng dan udang windu di Desa Mulyosari dan Desa Pasir Sakti Kecamatan Pasir Sakti menguntungkan dengan $\mathrm{R} / \mathrm{C}$ rasio biaya total sebesar 2,50 Sistem pemasaran ikan bandeng di Desa Mulyosari dan Desa Pasir Sakti Kabupaten Lampung Timur belum efisien.

\section{DAFTAR PUSTAKA}

Ali MF, Situmorang S, dan Murniati K. 2017. Analisis efisiensi pemasaran kubis di Kecamatan Gisting Kabupaten Tanggamus. JIIA Vol. 5. (3). Hal: 259-266. Universitas Lampung. Bandar Lampung. http://jurnal.fp. unila.ac.id/index.php/JIA/issue/view/153/. [4 Januari 2018].

Annisa R dan Lamusa A. 2014. Analisis kelayakan usaha tambak bandeng di Desa Dolago Kecamatan Parigi Selatan Kabupaten Parigi Moutong. e-J. Agro tekbis 2 (3) : 337-342. http://jurnal.untad. ac.id/jurnal/index.php/agrotekbis/article/v iew/3541/.[23 Januari 2018].

Direktorat Jenderal Perikanan Budidaya. 2016a. Statistik Budidaya-Ikan Bandeng di Indonesia Tahun 2013-2015. http://www.deptan.go.id/ [2 Mei 2016].

$2016 b$.

Sentra Produksi Ikan Bandeng-Buku Statistik Perikanan Budidaya di Indonesia Tahun 2013. http://www.deptan.go.id/. [2 Mei 2016].

Handayani D. 2011. Analisis Pendapatan Tumpang Sari dan Efisiensi Pemasaran wortel, bawang daun, dan lobak (Daikon) di Kawasan Agropolitan Kabupaten Cianjur. Skripsi. Universitas Lampung. Lampung.

Hasyim AI. 2012. Tataniaga Pertanian. Diktat Kuliah FP. Universitas Lampung. Bandar Lampung.

Kesuma R, Zakaria WA, dan Situmorang S. 2016. Analisis usahatani dan pemasaran bawang merah di Kabupaten Tanggamus. JIIA Vol. 4. (1). Hal: 1-7. Universitas Lampung. Bandar Lampung. http://jurnal.fp.unila.ac.id/index. php/JIA/issue/view/113/. [4 Januari 2018].

Mubyarto. 1989. Pengantar Ekonomi Pertanian. Edisi III. Pustaka LP3ES. Jakarta.

Soekartawi. 1995. Analisis Usahatani. UI Press. Jakarta.

Susanti S, Lestari D A, dan Kasymir E. 2017. Sistem pemasaran ikan patin (Pangasius $s p$ ) kelompok budidaya ikan sekar mina di Kawasan Minapolitan Patin Kecamatan Kota Gajah Kabupaten Lampung Tengah. JIIA Vol.5. (2). Hal: 116-123. Universitas Lampung. Bandar Lampung.http://jurnal.fp. unila.ac.id/index.php/JIA/article/view/1648/1 474/. [4 Januari 2018]. 